\title{
The Occupational Socialization of Athletic Administrators: A Content Analysis of Graduate Program Websites
}

\author{
Eddie Comeaux \\ University of California, Riverside \\ Kristina M. Navarro \\ University of Wisconsin-Whitewater \\ Aida Aliyeva \\ University of California, Riverside \\ Michael Salm \\ Alexa Frank \\ University of Wisconsin-Whitewater
}

\begin{abstract}
Employing occupational socialization as an interpretive framework, this study drew on a content analysis of athletic administration graduate program websites to explore the relationship between the programs and key issues facing professionals in the field of intercollegiate athletics. Results revealed that the processes and mechanisms in place to prepare graduate students for careers in intercollegiate athletics appear to be adequate, but could more comprehensively address the increasingly complex business enterprise of college sports, NCAA policies and rules, and key strategies to develop the academic talents of athletes. Formal processes, such as courses and experiential learning activities (e.g., internships, practica, field research) in the studied graduate programs, appeared to dominate role learning; informal processes or unintentional learning, such as interactions with peers and other campus stakeholders, appeared to be absent. This study highlights new directions for future work aimed at understanding the professional preparation of athletic administrators.
\end{abstract}

Keywords: athletic administration, intercollegiate athletics, graduate education, occupational socialization, commercialism

On April 7, 2015, the Duke University Blue Devils defeated the University of Wisconsin Badgers in the championship game of the $77^{\text {th }}$ annual National Collegiate Athletic Association (NCAA) men's basketball tournament. Approximately 28.3 million viewers tuned in to watch this contest, an increase of 33 percent from the previous year (Pallotta, 2015). The popularity of and interest in big-time college sports - that is, schools classified as members of the Division I Football Bowl Subdivision - continues, on average, to grow, and the funds that flow into athletics programs have created mass commercial entertainment with large monetary payouts (Bowen \& Levin, 2003; Eitzen, 2012). Moreover, for the fiscal year ending in 2015, the total revenue received by the NCAA exceeded \$1 billion (NCAA, 2015), indicating the undeniable existence of economic and commercial interests in college sports. 
With increasing expansion of the business enterprise that is college athletics, as well as ongoing changes to the core functions of athletics departments (see Navarro, Houston, Bernhard, Haslerig, \& Raphael, 2016), stakeholders in athletics affairs now serve in more public roles. These stakeholders-including athletic directors, compliance officers, financial and business officers, coaches, and practitioners who support athletes-require trustworthy, competent, forwardthinking, accountable leaders who can manage athletic departments' daily operations and support athletes without compromising the fundamental mission and values of the postsecondary institutions (Comeaux, 2013; Lumpkin, Stoll, \& Beller, 2012). Indeed, given the increasing changes to the college athletics landscape, there is a need for specialized pre-career training for athletic administrators 1 - training that is generally acquired through graduate education (Comeaux, Brown, \& Sieben, 2015; Navarro et al., 2016). As such, we must focus more squarely on athleticrelated graduate and professional programs in order to understand more clearly how they prepare and socialize athletic stakeholders for careers as athletic administrators.

\section{Sport-Related Graduate Programs}

Over the last half-century, more than 250 sport-related graduate programs, e.g., athletic administration, higher education or student affairs, sport management, sport studies, and sport leadership, have been created in the United States (Chelladurai, 2001; Parkhouse \& Pitts, 2004). These programs have been designed primarily to prepare individuals for a variety of leadership positions in athletic programs. While there are some reliable indicators related to professional preparation and occupational success in intercollegiate athletics (see Cuneen, 1992; Spenard, 2011), there has been surprisingly limited attention to the aim and scope of sport-related graduate programs and the extent to which they prepare individuals with the core competencies and skills they need to solve problems and adequately address increasingly complex issues.

One indicator of the aim and scope of a graduate or professional program is its website, as it typically provides current and prospective students with relevant programmatic information (Association of College and Research Libraries [ACRL], 2015). Although these websites may not contain every programmatic detail, there are common or general content areas, including the program's mission, goals, objectives, curriculum, admission and academic policies, characteristics of the student body, costs and financial aid, personnel, co-curricular activities, and the value of the program and degree (ACRL, 2015; Commission on Institutions of Higher Education, 2015; Hartley \& Morphew, 2008; Morphew \& Hartley, 2006)

Based on the clear gap in our knowledge about the professional training of academic administrators, the primary intent of the current study was to systematically investigate athletic administration graduate program websites in order to better understand the processes and mechanisms that prepare individuals for careers in intercollegiate athletics. To be eligible for inclusion in this study, an athletic administration graduate program had to be designed to provide a general understanding of higher education as a field of practice and inquiry as well as to prepare students primarily for leadership positions in intercollegiate athletics. Of the growing sport-related graduate programs, this study focused on programs rooted in higher education because they are more likely to prepare students for specific careers in athletics. The focus also was solely on

\footnotetext{
1 "Athletic administrators" refers to athletic directors, compliance officers, business and financial officers, public relations officers, coaches, academic advisors, counselors, staff, and tutors.
} 
graduate-level programs because undergraduate majors specifically for intercollegiate athletic administrators rarely exist. Academic program websites provided insight into what information the programs formally share with current and prospective students, thereby offering insight into the programs themselves (ACRL, 2015).

A review of the related literature (e.g., ACRL, 2015; Hartley \& Morphew, 2008; National Postsecondary Education Cooperative [NPEC], 2009) revealed parameters or general content areas for analysis of program websites to consider: institutional/program mission, program goals and objectives, curriculum or degree requirements, admission requirements, cost of education and availability of financial aid, academic policies, personnel, co-curricular activities, and the value of a program and degree. While this examination of program websites does not tell the entire story of the ways in which a set of programs prepare athletic administrators, it does shed light on the extent to which the individuals who enroll in them are prepared for the expectations of their future careers.

\section{Review of Literature}

\section{College Sport as a Profession}

College sport, by definition, is nested within higher education, yet it has grown increasingly commercialized (Bowen \& Levin, 2003). In fact, a select group of institutions-namely, those classified as members of the NCAA Division I Football Bowl Subdivision-have developed into an industry known as "big-time sports" (Sperber, 2000). Each of these departments support upwards of 800 college athletes with 100-200 full-time staff, and budgets of \$100 million dollars or more (Equity in Athletics, 2014).

The core functions of athletic departments have expanded from coaching and administering athletic competitions to the oversight of all aspects of college athletes' experiences and the dayto-day operations of multimillion-dollar corporations. At the same time, a growth in professional staff well beyond coaches and a few administrators has also occurred. In fact, many athletic departments now employ staff in such specific areas as video editing, marketing, development/fundraising, compliance, communications, recruiting, licensing, financial management, ticketing, sales, and academic support. This specialization has resulted in a need for specific professional training and foundational knowledge - a body of knowledge that has increasingly been sought through graduate education.

\section{Athletic Administration Graduate Programs}

The traditional route to a job in an athletic department has been through experiential learning, namely by being a coach or athlete or by completing an internship (Mullin, 1980). While athletics is a field that still greatly values related experience, there has also been growing acknowledgment of the need to develop a formal body of knowledge for practitioners. This formalization started in 1966 with the creation of the first sport management program at The Ohio University (Stier, 1993); since then, the field has seen astounding growth. In 1978, there were 23 sport management programs (Parkhouse, 1978); in 1992, there were 570 (Lambert, 1999), and, just three years later, in 1995, there were over 1,100 programs at the associate's, bachelor's, 
master's, and doctoral levels (Jones, Brooks, \& Mak, 2008). These programs have historically been housed in physical education departments and have offered a broad curriculum that, as the name implies, seeks to train sport managers (Hardy, 1987). And even as the curricula have developed and been fine-tuned over the years-breaking into subdisciplines such as kinesiology and recreation - the programs have remained heavily business-minded (Ulrich \& Parkhouse, 1982).

While sport management programs may serve leaders or managers in a general sport sense (e.g., recreational, professional), or even those interested in the business side of college sports (e.g., fundraising, ticketing, sales), they may not address the unique complexities of intercollegiate athletic departments or of the departments that work directly with college athletes. In fact, there is a strong focus on the need for administrators who work directly with athletes to have specialized training similar to their campus counterparts in student affairs and higher education (Navarro, 2014) - training that should focus on both the individual and organizational context.

Practitioners who work in academic or career counseling roles must have a clear understanding of the development stages that individuals traverse during their college years, as well as an understanding of the context in which those individuals operate (Brown, 2012). Further, college athletes are encouraged to integrate into the larger campus environment and overcome boundaries of athletics space and place (Bell \& Bernhard, 2015), and athletics practitioners must also be trained with this integration in mind. Thus, without purposeful attention to student development theory and the organizational structure of higher education, sport management programs may not serve those who need a foundational understanding of the college athlete experience (Jones et al., 2008). This points to the need for a different type of program (Comeaux et al., 2015).

As such, a new graduate track has emerged: programs with a concentration in intercollegiate athletic administration housed in departments or graduate schools of education. This nesting of athletics within education is both symbolic and practical, as it mirrors the physical spaces on campus and acknowledges the inherent relationship between athletic departments and institutions. Previous research has found that these programs serve students by integrating theory with practice and focusing on the experiences of the college athlete, and may be particularly attractive to individuals interested in working specifically at the college level or directly with athletes (Navarro et al., 2016). Although the research on today's niche programs in higher education is limited, these programs have the potential to create additional depth and breadth of training for future scholar-practitioners in intercollegiate athletics.

\section{Occupational Socialization in Intercollegiate Athletics}

In order to describe the socialization experiences of athletic administrators, this study employed occupational socialization as a conceptual framework. Occupational socialization is a complex, longitudinal process in which an individual acquires the skills and knowledge base to perform given tasks within a profession (Brown, 2012; Weidman et al., 2001). Related to teacher education programs, Lawson (1986) defined occupational socialization as "the process by which physical educationalists learn the knowledge, value, and skills required by the work organization" (p. 108). This framework has been used at the secondary level of education in the field of 
kinesiology (Curtner-Smith, 2001; Curtner-Smith, Hastie, \& Kinchin, 2008; Schempp \& Graber, 1992) as well as with teachers/athletic coaches (Brown, 2012; Brown \& Sieben, 2013). It has also been employed to understand graduate-level courses focused on intercollegiate athletics (Comeaux et al., 2015) and graduate and professional students in higher education (Weidman et al., 2001).

The occupational socialization process of athletic administrators can be understood across three phases - acculturation, professional socialization, and organizational socialization - that acknowledges the influence of precollege and college training, as well as workplace socialization (Lawson, 1986). For the purposes of this study, we focused on the phase of professional socialization, which includes formal education or graduate education, as well as informal processes that are part of preparation for a career in athletic administration (Brown, 2012). Sufficient preparation in a graduate program, role models, and informal encounters can aid in the development of aspiring athletic administrators.

There is little extant research on the professional socialization of athletic administrators. In a content analysis of courses focused on intercollegiate athletics in sport-related graduate programs, Comeaux et al. (2015) found that although course topics were consistent across syllabi, intercollegiate athletics courses tended to vary widely in their course purpose statements, course objectives, and major readings. Moreover, this study considered the question on course syllabi associated with the professional preparation of athletic administrators, and offered important insights into their formal training.

In light of the previous study that highlighted the content and structure of graduate students' coursework, the occupational socialization framework can serve as a useful tool for understanding the professional socialization of athletic administrators. Likewise, the interpretive framework can help to identify the central tenets and academic mechanisms of socialization through which students are prepared and socialized to the norms of professional practice in intercollegiate athletics. These mechanisms may include the content and structure of graduate programs as well as the informal relationships that aspiring athletic administrators establish with others (Miller, 2013).

\section{Methods}

To better understand the aim and scope of athletic administration graduate programs that are rooted in higher education and that prepare students for careers primarily in intercollegiate athletics, we used content analysis to analyze their program websites. Content analysis is defined as "a systematic, replicable technique for compressing many words of text into fewer content categories based on explicit rules of coding" (Stemler, 2001). Content analysis can serve as a method for studying communicated messages in a variety of forms (Holsti, 1969).

We explored academic program websites as platforms that convey specific, helpful information so that current and prospective students better understand the aim and scope of the programs. Although the purpose of a given academic website is arguably to promote a program and attract and convince prospective students to enroll in that program using search engine optimization strategies, it can also offer valuable insight into the program, including the program description, course outlines, and graduate attributes (ACRL, 2015). 


\section{Sampling}

We utilized purposeful sampling methods in this study. Before analyzing websites of athletic administration graduate programs, it was necessary to develop a list of athletic administration graduate programs that are rooted in American higher education. Our online searches resulted in the identification of 28 such programs. After we determined that many of these were not eligible for participation, either because they were not designed to provide a general understanding of higher education as a field of practice and inquiry, or their programs did not primarily lead to careers in intercollegiate athletics (as evidenced by the information on their websites), we included a total of seven graduate programs in our sample. The small sample size $(\mathrm{N}=7)$ indicates that the findings should be considered provisional, although it is worthwhile to note that the sample size is generally consistent with previous content analysis studies (Garvis \& Manning, 2015; Peng et al., 2014; Wu, 2013).

\section{Procedure}

To perform a content analysis of the seven websites included in this study, we began by reviewing one website to get a general sense of the text data (Creswell, 2008). We used an open coding method during this initial process to determine categories that fit the data (Berg, 2007). Then, as described above, we drew from the existing literature (e.g., ACRL, 2015; Hartley \& Morphew, 2008; NPEC, 2009) and from the model website to generate a detailed list of analytic categories: program mission, program goals and objectives, curriculum or degree requirements, admission requirements, co-curricular activities, and the value of the program and degree.

In order to maintain consistency in coding and establish inter-rater reliability, a member of the research team created a tentative coding sheet with related categories that was revised during the initial coding calibration process. During our revision of the coding sheet, we worked together to develop a coding scheme to analyze the program websites in a more systematic fashion. When all program websites were coded, we created a summary sheet of the findings for each site.

\section{Findings}

The graduate programs represented by the seven reviewed websites offer the master of arts (MA) degree $(n=3)$, master of education (MEd) degree $(n=2)$, and the master of science (MS) degree $(n=2)$. They are housed in colleges and schools of education $(n=5)$, a college of business $(\mathrm{n}=1)$, and a college of arts and sciences $(\mathrm{n}=1)$.

With respect to program degree requirements, we found that in order to graduate from the programs, students must successfully complete 48 units $(n=1), 36$ units $(n=3), 33$ units $(n=2)$, or 30 units $(n=1)$. Most of the programs $(n=6)$ require an internship experience, and some $(n=$ 3 ) require a capstone project or thesis; others $(n=3)$ do not require a capstone project or thesis. One of the program websites did not indicate whether a capstone project or thesis was required.

In terms of admission requirements, all of the programs required official transcripts and a letter of intent, and GRE scores were required only for MA degrees. Most of the programs required a minimum undergraduate grade point average of 3.0 for admission. In the following sections, we 
highlight findings from each of the relevant categories established during the analysis of program websites.

\section{Program Mission}

Each of the websites stated the graduate program's mission, although some statements were clearer and more comprehensive than others. The variation in their stated missions might be expected, but they all had a general theme related to preparation for careers in intercollegiate athletics. For instance, one graduate website stated the program's purpose was "integrating theory and practice to prepare graduate students for leadership positions in intercollegiate athletics." Another described the program as "flexible, student-centered," designed to produce "future scholar-practitioner leaders in higher education athletic administration." Similarly, another program's mission was "To offer students a graduate degree and practical athletic department internship experience in order to begin a fulfilling career in intercollegiate athletics."

\section{Program Goals and Objectives}

The majority of the websites did not include clearly stated program objectives. Two websites did include one broad theme: to prepare individuals who aspire to leadership positions in intercollegiate athletics. In light of increasing concerns related to the business or increasing commercialization of college athletics (see Bowen \& Levin, 2003; Eitzen, 2012; Knight Commission on Intercollegiate Athletics, 2010), it is worth noting that although the only program objective identified in this study was broadly defined, there appeared to be omissions of objectives explicit to understanding these particular concerns with the exception of one studied program that addressed this topic.

\section{Course Topics}

Our analysis of course topics revealed several prevalent topics related to intercollegiate athletics. These included governance and compliance $(n=4)$, leadership and management $(n=5)$, business and finance $(n=6)$, legal issues $(n=5)$, ethics $(n=5)$, and policy issues $(n=2)$. Also present were topics more closely related to the students themselves, such as the college athlete experience $(n=6)$, social issues (e.g., race, gender, class; $n=5)$, and best practices for practitioners in academic support centers $(n=2)$. Overall, there appeared to be limited attention to student academic support and NCAA policies and rules.

\section{Practicum and Internship Experiences}

There was some consistency in descriptions of internship and practicum experiences across program websites. All but one of the sites offered experiences that appeared to be specifically aligned with opportunities in the home institution's athletics department. In turn, the athletics department served as a type of learning laboratory to support high impact practices. Within these six programs, graduate students were given the opportunity to connect theory to practice within multiple units of the institution's athletics department via sound scholar-practitioner relationships.

\section{Value of Education and Degree/Placement}


All of the graduate program websites in this study acknowledged the importance of promoting (to the public) their desired program outcomes as well as the value of the education and degree they provided. One website, for example, indicated the types of leadership positions program graduates pursued: "Our graduates compete for positions as trainers, adult educators, program planners, distance education specialists, administrators, athletic administrators, and instructors in adult education organizations, colleges and universities, governmental and military agencies, and business and industry." Similarly, one site listed alumni and their current titles and affiliations; others provided statistical data on alumni placement.

\section{Discussion}

The purpose of this study was to explore the websites of graduate programs focused on athletics to better understand the professional socialization of athletic administrators. Seven websites were analyzed through the use of content analysis. Throughout this discussion, some limitations will emerge that suggest that caution should be used in making generalizations from our data. Nonetheless, this exploratory study achieved its objective. Our findings offer insights into the professional socialization of athletic administrators that were not previously available, and thus broaden our understanding of more general issues and lead to additional research questions deserving of inquiry.

Across the websites included in this analysis, there was variation in the program mission statements. The sites highlighted the programs' primary focus on linking theory and practice and developing practitioners, as well as on providing students with opportunities to gain practical athletics experience. This finding indicates general agreement in terms of the values and intended directions for developing the academic talents and skill sets of future athletic administrators.

Relatedly, our study also revealed that most program websites either did not clearly state program objectives or did not state them at all. It would be instructive for program websites to make clear and explicit their program objectives so that students know what they are expected to achieve. This does not necessarily suggest that program developers did not value or consider program objectives. In fact, although they may or may not have seriously considered objectives when creating their programs, standardized guidelines or frameworks to help them identify such constructs do not exist. Without standards or guidelines, it is likely that graduate program developers must rely on their own and others' expertise and experience in determining the aim and scope of their program, and in deciding precisely how students should be prepared for a career in athletic administration.

It is surprising that, with the exception of one program in this study, there were no explicit references to the big business of intercollegiate athletics in program missions and objectives. The mission and objectives should provide context and meaning for the graduate student experience and help clarify the practical aspects of what the program will actually do. It would be naïve, however, to believe that because the business aspects of college athletics are not included on a graduate program website that they are not covered to some degree in one or more program courses. Indeed, six of the seven programs had course offerings in business/finance. Nevertheless, the exclusion from these websites of these specific issues and concerns in college sports does 
suggest a deficiency in communication between the program developers and current and prospective students. As well, it is plausible that this glaring omission may convey the message that concerns such as the business aspects of college athletics are not as important for the professional socialization of athletic administrators or as central to program objectives.

Many course topics related to intercollegiate athletics were not consistent across the graduate program websites in this study, and this is likely due to the lack of a unifying model for instructional design. The inclusion of the business/finance topic, for example, may indicate that these programs are giving some attention to athletics spending and the business enterprise of college athletics - an ongoing concern at many colleges and universities (Fulks, 2010; Knight Commission on Intercollegiate Athletics, 2010). On the other hand, course topic coverage of NCAA policies and data-driven practices in academic support centers for athletes received little to no attention, which is consistent with Comeaux et al.'s (2015) recent findings.

This finding may in fact speak to the lack of NCAA policy discussions as well as professional preparation and data-driven intervention strategies among athletic administrators in graduate programs, both to understand and ensure college athletes' rights and well-being and to effectively develop their academic talents (Comeaux, 2015a, 2015b). In addition, to some degree this finding supports the notion that intercollegiate athletics courses have not yet developed to the point where there is a strong base of experts who can provide specific direction for the intent of these courses while allowing instructors to individualize courses as they deem appropriate. As such, course topics developed by experts in the field and shared systematically with a community of educators can provide a valuable framework for advancing graduate-level courses focused on intercollegiate athletics.

In spite of the relative diversity of course topics in these graduate-level programs, our findings revealed consistency in other areas. Most notably, all but one of the websites indicated the program offered practicum and internship experiences for students. This signals that these graduate programs understand the value and importance of effective pedagogical approaches such as experiential learning (e.g., internships, field research, service-learning projects) to maximizing graduate student preparation for careers in intercollegiate athletics (see Kolb \& Fry, 1975). Graduate students have the opportunity to reflect on and actively engage in sound, real-world experiences outside of the traditional classroom setting in order to enhance their knowledge and skills within athletics settings.

Looking through an occupational socialization analytical lens, there seem to be formal processes within these programs that are designed to help students develop the competencies and skills to serve as athletic administrators. In particular, although the written content in each area of the websites was, on average, limited, it is logical to conclude that they nevertheless offered a curricular structure, including foundational courses and developmental activities such as internships, aimed at enhancing students' literacy concerning their role as athletic administrators. It was not clear through the studied websites, however, whether students would gain an understanding of their roles and responsibilities through informal processes or unintentional learning (e.g., interactions with peers and campus stakeholders or observations in different contexts such as professional conferences). This aspect of a graduate program is critical, considering it is well-documented that new professionals gain insight into their roles in part 
through informal processes (Froehlich, 2005; Harvey \& Struzziero, 2008; Kathrein, 1990; Pitney \& Parker, 2009)

Finally, in terms of featuring the educational value and career benefits for students, there was consistency across the studied graduate program websites. The sites primarily identified and highlighted program graduates who had been successfully placed in the industry, and in some cases provided statistical data to support their job placement history. One plausible explanation for promoting these outcomes is that the graduate programs may understand the competitive nature of the athletics industry as well as student desires to find gainful employment during or immediate following graduation (Hutchinson, 2008).

\section{Conclusion and Implications}

Athletic administrators develop skills and learn their roles through a longitudinal process, including formal education. Based on our content analysis of graduate program websites, athletic administration graduate programs rooted in higher education appear to be an adequate but not completely sufficient basis for helping athletic administrators learn their responsibilities and prepare for an increasingly complex business enterprise. Formal processes in graduate programsone professional socialization strategy — did appear to dominate role learning in this study; more informal processes seemed to be absent.

Each of the seven program websites offered content that included core courses and experiential learning activities designed to enhance students' learning and personal development in athletics settings. These formal processes comprised co-curricular activities and a range of listed courses, yet limited attention was given to course topics such as best practices in academic support centers for athletes or NCAA policies. Given what we know about professional socialization, it might be wise for educators to consider competencies intended as optional frameworks for preparation program curricula for graduate students who aspire to athletic administration positions.

In 1992, the National Association for Sport and Physical Education (NASPE) and the North American Society for Sport Management (NASSM) identified curricular standards and established a review process for approving sport management programs (Parkhouse \& Pitts, 2004). Despite this progress, most sport management programs currently do not seek approval. This is largely due to program developers' disagreements with the established NASPE-NASSM content areas as well as concerns with where sport management programs are located (e.g., colleges of business, physical education, recreation), because students may not receive sufficient coursework specific to preparing sport management professionals (Laird, 2005). The graduate programs in the present study may want to learn from the problem areas and strengths of this framework - and build on it. As well, in the absence of any official requirements of content for athletic administration graduate programs, the role the present study can play in helping educators develop their own athletic administration curricula takes on greater significance.

Educators in these studied graduate programs should also consider new and imaginative ways to combine formal and informal processes as preparation for careers in athletic administration. If these graduate programs are already making use of a variety of formal and informal processes, it would be instructive for programs to make them explicit on their website. It 
is worth noting that we are not suggesting a one-size-fits-all approach to student learning and personal development - some variance in coursework is appropriate and could even be considered beneficial, given that graduate programs may differ in their foci and context.

Across the websites, we discovered little evidence or mention of professionalism and commercialism in intercollegiate athletics. With the increasing commercialization and entertainment aspects of college sport, we know that athletic administrators face incredible challenges ahead. Eligibility, financial, and sexual abuse scandals, excessive athletics spending, and dismal graduation rates in the revenue-generating sports of football and men's basketball have been the subject of intense public scrutiny for over a decade now (see Pearson \& Brady, 2013; Stubbs, 2016; Tamasco, 2016). These increasing pressures require athletic administrators to foster greater accountability and transparency; they must be better prepared with the competencies and skills to lead, solve problems, develop athletes' academic talents, and establish competitive, sustainable, and financially responsible athletic programs without compromising the educational mission and fundamental values of a college or university. This is a demanding and complex process, and one that requires more innovative, forward-thinking, and bold leadership from a diversity of stakeholder groups.

Right now, the time is ripe for educators and coordinators of athletic administration graduate programs to focus more squarely on professional socialization in order to effectively prepare and socialize students for careers in the commercialized, multibillion-dollar industry of college sports. The present study reveals that the processes and mechanisms that prepare graduate students for careers in intercollegiate athletics are likely adequate, but they can also be improved to more fully address the increasingly big business of college sports, NCAA policy concerns, and the lack of effective data-driven strategies in academic support centers for athletes. It would be wise for experts in the field to develop competencies as well as to propose new course topics and texts that would advance our training of the next generation of athletic administrators while intentionally enriching the intercollegiate athletics enterprise.

\section{Future Research}

The present study produced useful findings and has implications for educators of athletic administration graduate programs, as outlined above, but it also has limitations. For one, we were unable to unpack content on the studied programs' websites to explain their actual impact on graduate student preparation, engagement, and learning. Future qualitative studies exploring the experiences of current and/or past graduate students in intercollegiate athletic graduate courses should assess and evaluate this phenomenon in greater depth while potentially focusing on one or more phases of occupational socialization, including acculturation, professional socialization, and organizational socialization. Moreover, studies that explore this issue quantitatively on a broad range of outcomes could confirm whether these results are robust. In the future, it would be prudent to replicate this study with a broader sample of athletic administration graduate program websites, particularly as more of these programs are established.

Beyond the scope of this study but equally important for future research is the processes through which individual preparation and learning directly or indirectly influences organizational learning; it suggests that such an examination should include an analysis of organizational learning 
of new and existing members in athletic departments (see Comeaux, 2015c). In spite of these shortcomings, the present study can assist educators in further developing graduate programs by synthesizing and analyzing existing online content. It provides a valuable foundation on which to understand athletic administration graduate programs and their relationship to graduate student preparation for careers in intercollegiate athletics. 


\section{References}

Association of College and Research Libraries. (2015). Characteristics of programs of information literacy that illustrate best practices: A guideline. Retrieved from http://www.ala.org/acrl/standards/characteristics

Berg, B. L. (2007). Qualitative research methods for the social sciences (6 ${ }^{\text {th }}$ ed.). Boston: Allyn and Bacon.

Bernhard, L. M., \& Bell, L. (2015). Best practices in academic support services for studentathletes: Considerations for location. In E. Comeaux (Ed.), Data-informed practices in academic support centers for college athletes (pp. 125-142). Charlotte, NC: Information Age Publishing.

Bowen, W. G., \& Levin, S. A. (2003). Reclaiming the game: College sports and educational values. Princeton, NJ: Princeton University Press.

Brown, A. (2012). The occupational socialization of novice, core content area teacher/athletic coaches (Doctoral dissertation). Retrieved from The University of Alabama.

Brown, A., \& Sieben, N. (2013). The elephant in the classroom: Examining the influence of athletic coaching on secondary preservice teachers. Teacher Education Quarterly, 40(3), $107-122$.

Chelladurai, P. (2001). Managing organizations for sport and physical activity. Scottsdale, AZ: Holcomb Hathaway.

Comeaux, E. (2013). Rethinking academic reform and encouraging organizational innovation: Implications for stakeholder management in college sports. Innovative Higher Education, $38,281-293$.

Comeaux, E. (Ed.). (2015a). Introduction to intercollegiate athletics. Baltimore, MD: Johns Hopkins University Press.

Comeaux, E. (Ed.). (2015b). Making the connection: Data-informed practices in academic support centers for college athletes. Charlotte, NC: Information Age.

Comeaux, E. (2015c). Organizational learning in athletic departments: Toward an anti-deficit and data-driven approach to academic support for division I athletes. In E. Comeaux (Ed.), Making the connection: Data-informed practice sin academic support for college athletes (pp. 1-16). Charlotte, NC: Information Age Publishing.

Comeaux, E., Brown, A., \& Sieben, N. P. (2015). Issues in athletic administration: A content analysis of syllabi from intercollegiate athletics graduate courses. Innovative Higher Education, 40, 359-372. 
Commission on Institutions of Higher Education (2011). Public disclosure. Retrieved from https://cihe.neasc.org/information-public/public-disclosure

Creswell, J. W. (2008). Research design: Quantitative, qualitative, and mixed methods approaches ( $3^{\text {rd }}$ ed.). Thousand Oaks, CA: Sage.

Cuneen, J. (1992). Graduate-level professional preparation for athletic directors. Journal of Sport Management, 6, 15-26.

Curtner-Smith, M. D. (2001). The occupational socialization of a first-year physical education teacher with a teaching orientation. Sport, Education and Society, 6, 81-105.

Curtner-Smith, M. D., Hastie, P. A., \& Kinchin, G. D. (2008). Influence of occupational socialization on beginning teachers' interpretation and delivery of sport education. Sport, Education and Society, 13, 97-117.

Eitzen, D. S. (2012). Fair and foul: Beyond the myths and paradoxes of sport. New York, NY: Rowman \& Littlefield.

Equity in Athletics. (2014). U.S. Department of Education Data Analysis. Retrieved from http://ope.ed.gov/athletics/\#/datafile/list

Froehlich, A. C. (2005). Does the curricular structure affect doctoral enrolment? Journal of Business Economics, 1, 1-23. doi:10.1007/s11573-016-0812-X

Fulks, D. L. (2010). Revenues \& expenses 2004-2009: NCAA Division I intercollegiate athletics programs report. Indianapolis, IN: National Collegiate Athletic Association.

Garvis, S., \& Manning, M. (2015). Do master early childhood teacher education programs provide adequate coverage of infants and toddlers? A review of content. Australian Journal of Teacher Education, 40(8), 164.

Hardy, S. (1987). Graduate curriculums in sport management: The need for a business orientation. Quest, 39, 207-216.

Hartley, M., \& Morphew, C. C. (2008). What's being sold and to what end? A content analysis of college viewbooks. Journal of Higher Education, 79, 671-691.

Harvey, V. S., \& Struzziero, J. A. (2008). Professional development and supervision of school psychologist: From intern to expert ( $2^{\text {nd }}$ ed.). Thousand Oaks, CA: Sage.

Holsti, O. R. (1969). Content analysis for the social sciences and humanities. Reading, MA: Addison-Wesley. 
Hutchinson, M. D. (2008). Early career development in the sport industry: Factors affecting employment (Unpublished master's thesis). Retrieved from http://repository.tamu.edu/bitstream/handle/1969.1/ETD-TAMU-2760/HUTCHINSONTHESIS.pdf? sequence $=1$

Jones, F.D., Brooks, D., \& Mak, J. (2008). Examining Sports Management Programs in the United States. Sports Management Review, 11(1), 77-91.

Kathrein, M. A. (1990). Continuing nursing education: A perspective. The Journal of Continuing Education in Nursing, 21, 216-218.

Knight Commission on Intercollegiate Athletics. (2010). Restoring the balance: Dollars, values, and the future of college sports. Miami, FL: Author.

Kolb, D. A., \& Fry, R. (1975). Toward an applied theory of experiential learning. In C. Cooper (Ed.), Theories of group process (pp. 33-57). London, England: John Wiley.

Laird, C. (2005). The influence of sport management program characteristics on academician perceptions of NASPE-NASSM approval. The SMART Journal, 1(2), 4-13.

Lambert, T. (1999). Thorstein Veblen and the higher learning of sport management education. Journal of Economic Issues, 33, 973-984.

Lawson, H. A. (1986). Occupational socialization and the design of teacher education programs. Journal of Teaching in Physical Education, 5, 107-116.

Lumpkin, A., Stoll, S. K., \& Beller, J. M. (2012). Practical ethics in sport management. Jefferson, NC: McFarland.

Miller, S. E. (2013). Professional socialization: A bridge between the explicit and implicit curricula. Journal of Social Work Education, 49, 368-386.

Morphew, C. C., \& Hartley, M. (2006). Mission statements: A thematic analysis of rhetoric across institutional type. Journal of Higher Education, 77, 456-471.

Mullin, B. (1980). Sport management: The nature and utility of the concept. Journal of Sport and Social Issues, Arena Review, 4(3)

National Collegiate Athletic Association. (2015). NCAA finance. Retrieved from http://www.ncaa.org

National Postsecondary Education Cooperative (2009). Information required to be disclosed under the higher education act of 1965: Suggestions for dissemination. Retrieved from http://nces.ed.gov/pubs2010/2010831rev.pdf 
Navarro, K. M. (2014). A conceptual model of Division I student-athletes' career construction processes. College Student Affairs Journal, 32(1), 45-60.

Navarro, K. M., Houston, D., Bernhard, L. M., Haslerig, S., \& Raphael, V. (February, 2016). Athletic administration and higher education graduate programs: Innovative strategies and campus partnerships to prepare the next generation of intercollegiate athletic administrators. Journal for the Study of Sports and Athletes in Education, 9(3), 1-18.

Pallotta, F. (2015). March madness is a TV slam dunk: Highest ratings in 22 years. CNNMoney. Retrieved from http://money.cnn.com/2015/04/07/media/march-madness-tv-ratings/

Parkhouse, B. L. (1978). Professional preparation in athletic administration and sport management: Graduate programs in the United States. Journal of Physical Education and Recreation, 49(5), 22-27.

Parkhouse, B. L., \& Pitts, B. G. (2004). History of sport management. In B. L. Parkhouse (Ed.), The management of sport: Its foundation and application $\left(4^{\text {th }}\right.$ ed.; pp. 2-14). New York, NY: McGraw-Hill.

Pearson, M., \& Brady, B. (2013). Rutgers coach fired after abusive video broadcast. CNN Sports. Retrieved from http://www.cnn.com/2013/04/03/sport/rutgers-video-attack/

Peng, Y., Wu, X., Atkins, S., Zwarentein, M., Zhu, M., Zhan, X. X., ... \& Yan, W. R. (2014). Internet-based health education in China: A content analysis of websites. BMC Medical Education, 14(1), 1.

Pitney, W., \& Parker, J. (2009). Qualitative research in physical activity and the health professions. Champaign, IL: Human Kinetics.

Schempp, P. G., \& Graber, K. C. (1992). Teacher socialization from a dialectal perspective: Pretraining through induction. Journal of Teaching in Physical Education, 11, 329-348.

Spenard, J. C. (2011). Professional preparation of the NCAA division I athletic director: An occupational framework (Unpublished master's thesis). Retrieved from http://trace.tennessee.edu/cgi/viewcontent.cgi?article=2006\&context=utk_gradthes

Sperber, M. (2000). Beer and circus: How big-time college sports has crippled undergraduate education. New York, NY: Macmillan.

Stemler, S. (2001). An overview of content analysis. Practical Assessment, Research \& Evaluation, 7(17). Retrieved from http://pareonline.net/getvn.asp?v=7\&n=17

Stier, W. F. (1993). Alternative career paths in physical education: Sport management. ERIC Digest, 1-6. 
Stubbs, R. (2016, August 2). UNC challenges NCAA's authority to make the most serious charges in academic scandal. The Washington Post. Retrieved from https://www.washingtonpost.com/news/sports/wp/2016/08/02/north-carolina-respondsto-ncaas-notice-of-allegations-on-academic-fraud/

Tamasco, B. (2016, April 14). A quick, complete guide to the Baylor football sex-assault scandal. The Dallas Morning News. Retrieved from http://crimeblog.dallasnews.com/2016/04/howa-sexual-assault-scandal-engulfed-baylors-football-program.html/

Ulrich, D., \& Parkhouse, B. (1982). An alumni orientated approach to sport management curriculum design using performance ratings and a regression model. Research Quarterly for Exercise and Sport, 53, 64-72.

Weidman, J. C., Twale, D. J., \& Stein, E. L. (2001). Socialization of graduate and professional students in higher education: A perilous passage? ASHE-ERIC Higher Education Report, 28(3).

Wu, Y. (2013). A preliminary study on the curriculum overlap and gap between LIS education and intelligence education. Journal of Education for Library and Information Science, 54, 270 285. 